\title{
The comparison of Post-Operative Complications pre Covid era versus during Covid-Era based on Clavien-Dindo-classification: A Systematic Review and Meta-Analysis
}

Yeganeh Farsi ${ }^{1 *}$, Fatemeh Shojaeian ${ }^{2 *}$, Seyed Amir Ahmad Safavi-Naini ${ }^{3 *}$, Mohammadjavad Honarvar $^{4}$, Benyamin Mohammadzadeh ${ }^{5}$, Mohammad Javad Nasiri**

1. Yeganehfarsi@sbmu.ac.ir, 0000-0002-4636-6572, Student research committee, school of medicine, Shahid Beheshti University of medical sciences, Tehran, Iran

2. fshojae1@jhmi.edu, 0000-0001-5972-9953, Sidney Kimmel Comprehensive Cancer Center, Johns Hopkins University School of Medicine, Baltimore, Maryland, US.

3. amirsafavi@sbmu.ac.ir, 0000-0001-9295-9283, Research Institute for Gastroenterology and Liver Diseases, Shahid Beheshti University of Medical Sciences, Tehran, Iran.

4. mj.honarvar@sbmu.ac.ir, 0000-0002-3650-4951, Student research committee, school of medicine, Shahid Beheshti University of medical sciences, Tehran, Iran

5. Benyamin.mohammadzadeh@sbmu.ac.ir, 0000-0002-5070-8387, School of Medicine, Shahid Beheshti University of Medical Sciences, Tehran, Iran.

6. mj.nasiri@hotmail.com / 0000-0002-3279-0671 / Department of Microbiology, School of Medicine, Shahid Beheshti University of Medical Sciences, Tehran, Iran. PhD Assistant Professor of Medical Microbiology

*Theses authors are equally considered as the first author.

**The corresponding author 


\begin{abstract}
Introduction: Coronavirus Disease 2019 (COVID -19) pandemic challenged the healthcare system drastically, and it was concomitant with a remarkable decline in surgeries and modified routine care of patients worldwide. This systematic review and meta-analysis aimed to compare the surgical complications before COVID -19 (Pre-COVID) and after COVID -19 (post-COVID) appearance using the Clavien-Dindo classification (CDC).
\end{abstract}

Methods: between January 1, 2019, to November 3, 2021, we performed a comprehensive search in PubMed/Medline and Scopus for studies reporting the postoperative complications based on/transformable to CDC.

Result: From 909 screened articles, 34 studies were included for systematic review. Among included articles, 11 were eligible for meta-analysis. Nineteen thousand one hundred thirty-seven patients (pre-COVID: 3522, post-COVID: 15615) were included, mostly undergoing elective surgeries (86.32\%). According to CDC classification, there were no significant change between pre-COVID and post-COVID for grade 1 (Odds ratio (OR) and 95\% confidence interval (95-CI): $0.99,0.60-1.63, \mathrm{p}=0.96$ ), grade 2 (OR and 95-CI: 0.65, 0.42-1.01, $\mathrm{p}=0.055$ ), grade 3 (OR and 95-CI: 0.86, 0.48-1.57, $\mathrm{p}=0.64$ ), grade 4 (OR and 95-CI: 0.85, 0.46-1.57, $\mathrm{p}=0.60$ ). However, the postoperative mortality was lower before the COVID -19 outbreak (OR and 95-CI: 0.51, 0.27$0.95, \mathrm{p}=0.035)$. The included studies for systematic review and meta-analysis had a low risk of bias and unsignificant publication bias.

Conclusion: Although delivering routine surgery was challenging, the postoperative complications during the pandemic remained identical to the pre-pandemic era. The stricter patient selection tending to choose more critical states and more advanced clinical stages of the operated patients may explain some extent of higher mortality during the pandemic. Adopting preventive strategies helped deliver surgeries during the outbreak of COVID -19 while limiting the capacity of operations and admissions. 


\section{Introduction}

Coronavirus Disease 2019 (COVID -19), which was declared as a pandemic in March 2020, has expanded fast worldwide since its emergence in late December 2019 and claiming more than 5.6 million lives (1-3). The pandemic was wreaking havoc on all aspects of healthcare systems by overwhelming them with contagious patients and a newly appeared disease $(4,5)$. Sick patients with various signs and symptoms flooded hospitals and other medical institutions $(6,7)$; hence, they were unable to provide a wide range of procedures and surgeries while still ensuring the health and safety of patients and staff. Accordingly, an international call to postpone surgeries seemed crucial for as many as possible $(8,9)$.

The world and healthcare organizations have been gradually returning to normal as the virus has been contained. Since the surgical candidates were already facing prolonged delays, resuming surgeries was one of the earliest steps of this returning $(10,11)$. As a result, different hospitals have recommenced surgeries one by one, and the number of invasive procedures is rising all over the world. By continuing the reduction of lockdown restrictions, as well as flattening the exponential curve of the virus spread and its related death, a long waiting list for different types of procedures would be expected $(12,13)$. Evidently, the pandemic is ongoing with no end in sight, and the virus would continue to rule the healthcare systems. Considering some strategies appeared for patients' safety and protection, there would be a trade-off between the risk of performing surgeries during the pandemic and further postponement or cancellation $(14,15)$.

Taken together, CVID-19 seems to continue infecting individuals and running the healthcare systems and their policies; thus, there might be an urgent need to investigate whether resuming the surgeries was a drawback to the health condition of the patients and resulted in more surgical complications or not. Here, we are conceived to go into the complications of the patients who underwent surgery during the pandemic. Particularly, in this systematic review, we aimed to compare the surgical complications in various types of surgery, including urgent, emergent, and elective surgery, before and after COVID -19 appearance, using the Clavien-Dindo classification as a valuable, objective rating method for surgical complications (16).

\section{Methods}

\section{Search Strategy}

As we aimed to determine the outcomes of surgical procedures during the COVID era, we only considered publications between January 1, 2019 to November 3, 2021. The searched keywords included: COVID -19, SARS CoV 2, Coronavirus Disease 19, Surgery, operative therapy, invasive procedure, operative procedure, operation, perioperative procedure, intraoperative procedure, preoperative procedure, Clavien-Dindo, and postoperative complication. The study is performed based on the latest edition of PRISMA guidelines (17). 


\section{Study Selection}

The primary search results were organized by EndNote X8 (Thomson Reuters, New York, NY, USA) and duplicates removed. Two independent reviewers (FS and BM) evaluated the relevancy of the remaining articles based on the title and abstract. The remained full-text were assessed by the third reviewer (YF) and the data of eligible articles were extracted by two other reviewers (AS and $\mathrm{MH}$ ). The eligibility criterions for systematic review study selection were defined as: 1) Reporting the post operation complications based on Clavien-Dindo- Classification explicitly or transformable to Clavien-Dindo- Classification. 2) Study population as adult patients with negative pre operative RT-PCR of SARS- CoV-2 or unprobeable cases of COVID -19. 3) Comparing the post operative complications before and during the COVID era was an additional inclusion criterion for the selection of meta- analysis included studies. Case reports, editorials, commentaries, reviews, studies with insufficient data, and non- English articles were excluded. All steps were double checked and in case of disagreement, a third reviewer opinion was obtained.

\section{Data Extraction and Quality Assessment}

Two reviewers (AS and $\mathrm{MH}$ ) designed an agreed data extraction form and extracted the data of all eligible studies. The first author's name, date of publication, type of study, country of study conduction, mean age, study population, type of surgery, site of surgery, the reported or investigated Clavien-Dindo classification were extracted.

Type of surgeries based on urgency: According to the NCEPOD association, the surgeries can be categorized into four levels of urgency (18):

a) Immediate: Surgeries must perform in life-threatening conditions within minutes after the diagnosis.

b) Urgent: Surgeries in potentially life-threatening conditions which must perform within hours after the diagnosis.

c) Expediated: Surgeries which should perform early but it can be delayed for days.

d) Elective: Surgeries which are planned to perform at the optimum condition of the patient.

Clavien- Dindo classification of post operative complications: Surgical complications are categorized into five grades due to Clavien-Dindo classification (19):

I. Grade 1 is defined as any deviation from the normal expected recovery path, which does not require any specific treatment; the analgesics, anti- emetics, electrolyte, diuretics, physiotherapy, and the bedside wound infections opening are the allowed prescription and interventions.

II. Grade 2 is any medical treatment but the above.

III. Grade 3 is any intervention; Including surgical, radiologic and endoscopic. 
IV. Grade 4 is any life-threatening complication, required intensive care.

V. Grade 5 is death of the patient.

\section{Quality Assessment}

Two other reviewer (FS and YF) blindly assessed the quality of the included articles by the ROBINS-I ("Risk Of Bias In Non-randomized Studies - of Interventions") (20). The study population, methods of matching and controlling the confounding factors, the complication reporting system, follow up period, and statistical analysis were assessed with great concern.

\section{Data Synthesis and Analysis}

Statistical analyses were performed with Comprehensive Meta-Analysis software, version v3.7z (Biostat Inc, Englewood, USA). The heterogeneity was assessed by Cochran's Q and the $\mathrm{I}^{2}$ statistic. According to the estimated heterogeneity of the true effect sizes for each grade of complications, either the random effect model or the fixed effect model was used. The odds of complications between pre-COVID and COVID era groups with $95 \%$ confidence intervals (CI) were calculated. Begg's and Egger's tests were used to assess the publication bias and funnel plots illustrated it ( $p<0.05$ was indicative for statistically significant publication bias).

\section{Result}

The primary search result in databases revealed 909 articles, which finally 34 articles were included for qualitative analysis which 11 out of them were eligible for quantitative analysis (Figure 1). A summary of all included articles is provided in Table 1. A total of 19,137 patients (3522 patients in pre COVID era and 15615 patients during COVID era) were assessed in metaanalysis. According to ROBINS-I tool, the included studies for both systematic review and metaanalysis had low risk of bias (Supp.1). There was unsignificant publication bias which is expressed as Begg's and Egger's indexes (Table 2). Also funnel plots are provided in supp.2 to illustrate the publication bias.

\section{The urgency of operations and related organ systems}

Elective surgeries (including cancer surgeries) were the most common type of applied surgeries $(86.32 \%)$, followed by urgent (11.22\%), emergent and expediated surgeries.

Non- vascular abdominal surgeries, urologic/ gynecologic surgeries, and the cardiothoracic surgeries were the most common reported surgeries. All reported surgeries based on the related organ- system is noted in Table 3.

\section{Post operative complications}

Post operative complications are reported based on Clavien- Dindo classification. Table 4. Demonstrates the incidence of post operative complications in reviewed articles during the 
COVID era (Table 4). The incidence of each grade of post operative complication based on Clavien- Dindo classification, has been compared and meta- analyzed between pre COVID era and COVID era, illustrated in figures 2- 6. There was no significant difference between any grades of post operative complications between pre COVID era and COVID era (Table 2, 4, 5, Figures 2- 6).

\section{Discussion}

Since the COVID -19 outbreak in early 2020, almost all healthcare facilities worldwide have faced devastating damages from this pandemic. It has altered proper medical care by delays in diagnosis, treatment, and follow-up of patients(35). Massive employment of health care resources resulted in canceling and postponing surgeries. Some studies reported an increase in postoperative complications $(24,55,56)$. As far as we aware this study is among first systematic reviews studying on complication of surgeries during the pandemic so far. we collected and reviewed data to compare the rate of postoperative complications as classified by Clavien-Dindo Classification (CDC) before and during the COVID -19 outbreak. Although the surgery complications were comparable (grades 1 to 4), the post-operative mortality (grade 5) was higher during the pandemic compared to before the outbreak. The more advanced stage of the disease, delay in treatment, and more complicated patient selection may explain the lower survival after the surgery.

Several studies dedicate higher post operative morbidity and mortality among SARS- CoV-2 positive patients (56-59); but the impact of COVID -19 on surgical practice is not limited to SARS- CoV-2 positive patients. According to our meta-analysis, the COVID -19 negative patients who underwent surgery during the COVID -19 era are also endangered of greater mortality (60). Delay in hospital referral due to public fear of COVID -19, has led to more critical condition of patients at the admission time which was accompanied by more complicated surgical state and higher mortality, especially for emergency surgeries. $(24,27,61,62)$. On the other hand, health care providers preferred close observation and conservative management to surgery in patients with younger age and better overall health condition $(31,63,64)$ So the majority of operations were performed on elder adults with multiple comorbidities and more critical conditions with poorer prognosis $(24,33,34,46,52,65)$.

Studies from different contexts were included in our review. Different centers, countries, timelines, types of surgeries and guidelines were observed, which may affect the surgical complications. Changes in resources availability were also presented in most studies (REF?). Three out of the ten studies in our meta-analysis suggested significantly higher rate of postoperative complications (22) and one of the two reported more severe complications in the COVID -19 era compared to the control cohort (24). Both studies were conducted in the first COVID -19 wave in Italy which was one of the first countries to experience the SARS-COV-2 outbreak. Above all, these studies did not claim any specific screening or preventing protocols for COVID -19. In contrast, with the use of protection protocols, Panda et al. found a significant 
decrease in major post-operative complications during pandemic, and in a matched pair analysis, lower rate of complications (30). Evidence suggests that surgery care can be continued with adopting preventive strategies and protocols, even in the COVID -19 peak (23,26-29,42,49,54).

As Figure 8 depicts, many preventive strategies were implemented in an attempt to continue routine surgery care. A study on 7704 bariatric patients from 42 countries admitted in 185 centers showed $50 \%$ and $80 \%$ of centers practiced self-isolation and screening before surgery, respectively. Half of centers provided FFP3/N95 masks in the operation room and staffscreening was performed in third of hospitals. They found same complication rate during the pandemic and concluded it is safe to continue surgery care using preventive protocols (38). Moreover, COVID Surg Collaborative study on 9171 patients from 447 hospitals proved lower respiratory complication in hospitals with COVID -19-free pathway (66). A variety of protocols is evident in the literature at national, hospital, and department levels (Figure 8). Although some screening and protective measures are considered to be more effective, some of them are not feasible in low-resourced contexts. However, proper decisions at department and hospital level could successfully prevent complications regardless of shortage of resources.

Approaches of treatment in different settings were also affected by the pandemic and resulted in new guidelines and recommendations (64). Based on previous experience from viruses such as HPV, some initial guidelines had recommended limitation of laparoscopy procedures as it may carry the risk of surgical staff contamination (67). However, with employment of proper ultrafiltration and protection methods, studies not following this recommendation did not observe such side effect $(29,54)$ Moreover, recent guidelines recommended conservative treatment of uncomplicated appendicitis as a safe option with low failure rate especially in the COVID -19 pandemic $(68,69)$. Prioritization of the patients, ICU preserving techniques, laparotomy with regional instead of general anesthesia $(42,45)$ more extensive use of robotic surgery $(70)$, and distant/home patient monitoring and follow-up were put into test. Despite all limitations, it seems that the means and measures for lowering post-operative complications are effective. m-RNA vaccines have been created for COVID -19 offering hope for HIV prevention (71). Likewise, we hope development and employment of these new strategies in healthcare and surgery could lead to positive effect not only during pandemics but also in the future practice.

Studies in the available literature confirmed a decrease in admission rates $(21,22,24,32)$ which may be a result of patients' reluctancy to admission in fear of COVID -19. Prognostic factors and corresponding indices such as complications at presentation (e.g., perforation, abscess, etc.), Mannheim Peritonitis Index, American Association for the Surgery of Trauma (ASST) scores, and pathologic findings were significantly in favor of complexity $(21,22,24,27,28,42)$ and severity $(26,42)$ of the diseases in the COVID era. Changes in rate of admissions can also cause outcome bias. On one hand, elective surgeries (which have better prognosis) significantly decreased in some contexts $(22,29,32)$. On the other hand, less surgical admission along with strict COVID -19 protocols resulted in less operations and slower turnover of the patients which can be the reason for the favorable outcomes. 
Apart from the potential risk of COVID -19 itself, the recent pandemic has posed unprecedented challenges in terms of finance, resources, disease severity, and outcomes for the healthcare system around the world. Cancelation and subsequent long waiting list of elective surgeries, low capacity of hospital and ICU beds especially in the first months of pandemic can negatively affect surgeries $(12,13)$. The importance in preventing unnecessary delays in non-elective and cancer surgeries is irrefutable (72). Thus, preserving enough capacity for cancer surgery along with ongoing emergent surgeries is of great concern. In a center with no preoperative screening in asymptomatic patients, extraordinary hospital and ICU bed capacity along with protocols resulted in favorable outcomes (23). Overall delay in treatment may put the patient's life at risk and may explain some extent of higher mortality during the pandemic.

There are limitations when interpreting the results of this study. Many of included studies was conducted in developed countries, whereas studies from developing countries are scarce and no study was available on African population. This is important since the under-resourced countries face shortage of screening tools, lack of resource to change infrastructures, and less flexibility to adapt new strategies. Moreover, small samples were available for some of surgery fields such as ophthalmology, therefore the implementation of the results should be done with caution.

In conclusion, although delivering routine surgery was challenging, the perioperative complications during the pandemic remained identical to the pre-pandemic era. Precise patient selection and adopting preventive strategies helped deliver surgeries during the outbreak of COVID -19 while limiting the capacity of operations and admissions. Studies from middle- and low-income countries are scarce, where implementing new protocols is challenging. Future studies are warranted to confirm these results.

\section{Conflict of Interests}

The authors declare no conflict of interests related to this article

\section{Funding}

No funding was received for this work.

\section{Author Contribution}

Guarantor of article: YF

study concept and study supervision: $\mathrm{MN}$

study design: $\mathrm{MN}, \mathrm{YF}$

manuscript drafting: FS, AS, MH, BM

manuscript edition and final approval: all authors

data analysis and visualization: YF, AS

data collection and/or data interpretation: all authors 


\section{References}

1. Fahmi I. World Health Organization coronavirus disease 2019 (COVID -19) situation report. DroneEmprit. 2019;

2. Zhu N, Zhang D, Wang W, Li X, Yang B, Song J, et al. A Novel Coronavirus from Patients with Pneumonia in China, 2019. N Engl J Med. 2020;382(8):727-33.

3. Roser M, Ritchie H, Ortiz-Ospina E, Hasell J. Coronavirus pandemic (COVID -19). Our world data. 2020;

4. Okonkwo NE, Aguwa UT, Jang M, Barré IA, Page KR, Sullivan PS, et al. COVID -19 and the US response: accelerating health inequities. BMJ evidence-based Med. 2021;26(4):176-9.

5. Dorsett M. Point of no return: COVID -19 and the US healthcare system: An emergency physician's perspective. Vol. 6, Science Advances. American Association for the Advancement of Science; 2020. p. eabc5354.

6. Raoufi M, Ahmad Safavi Naini SA, Azizan Z, Jafar Zade F, Shojaeian F, Boroujeni MG, et al. Correlation between Chest Computed Tomography Scan Findings and Mortality of COVID -19 Cases; a Cross sectional Study. Arch Acad Emerg Med [Internet]. 2020;8(1):1-7. Available from:

http://www.ncbi.nlm.nih.gov/pubmed/32613199\%0Ahttp://www.pubmedcentral.nih.gov/a rticlerender.fcgi?artid=PMC7305634

7. Wang D, Hu B, Hu C, Zhu F, Liu X, Zhang J, et al. Clinical characteristics of 138 hospitalized patients with 2019 novel coronavirus-infected pneumonia in Wuhan, China. Jama. 2020;323(11):1061-9.

8. Spinelli A, Pellino G. COVID -19 pandemic: perspectives on an unfolding crisis. J Br Surg. 2020;107(7):785-7.

9. Brindle ME, Gawande A. Managing COVID -19 in surgical systems. Ann Surg. 2020;

10. Mouton C, Hirschmann MT, Ollivier M, Seil R, Menetrey J. COVID -19-ESSKA guidelines and recommendations for resuming elective surgery. J Exp Orthop. 2020;7:1-7.

11. Al-Omar K, Bakkar S, Khasawneh L, Donatini G, Miccoli P. Resuming elective surgery in the time of COVID -19: a safe and comprehensive strategy. Updates Surg. 2020;72:291-5.

12. Hale T, Angrist N, Goldszmidt R, Kira B, Petherick A, Phillips T, et al. A global panel database of pandemic policies (Oxford COVID -19 Government Response Tracker). Nat Hum Behav. 2021;5(4):529-38.

13. Flaxman S, Mishra S, Gandy A, Unwin HJT, Mellan TA, Coupland H, et al. Estimating the effects of non-pharmaceutical interventions on COVID -19 in Europe. Nature. 2020;584(7820):257-61.

14. Brücher BLDM, Nigri G, Tinelli A, Lapeña JFF, Espin-Basany E, Macri P, et al. COVID 19: Pandemic surgery guidance. 4open. 2020;3:1. 
15. Rubino F, Cohen R V, Mingrone G, le Roux CW, Mechanick JI, Arterburn DE, et al. Bariatric and metabolic surgery during and after the COVID -19 pandemic: DSS recommendations for management of surgical candidates and postoperative patients and prioritisation of access to surgery. Lancet Diabetes Endocrinol. 2020;8(7):640-8.

16. Miyamoto S, Nakao J, Higashino T, Yoshimoto S, Hayashi R, Sakuraba M. ClavienDindo classification for grading complications after total pharyngolaryngectomy and free jejunum transfer. PLoS One. 2019 Sep;14(9):e0222570-e0222570.

17. Yepes-Nuñez JJ, Urrútia G, Romero-García M, Alonso-Fernández S. The PRISMA 2020 statement: an updated guideline for reporting systematic reviews. Rev Esp Cardiol. 2021;74(9):790-9.

18. National Confidential Enquiry into Perioperative Deaths. The NCEPOD Classification of Intervention [Internet]. Ncepod. 2004 [cited 2022 Jan 29]. p. 1-3. Available from: www.ncepod.org.uk/pdf/NCEPODClassification.pdf?

19. Dindo D, Demartines N, Clavien PA. Classification of surgical complications: A new proposal with evaluation in a cohort of 6336 patients and results of a survey. Ann Surg. 2004;240(2):205-13.

20. Sterne JA, Hernán MA, Reeves BC, Savović J, Berkman ND, Viswanathan M, et al. ROBINS-I: a tool for assessing risk of bias in non-randomised studies of interventions. BMJ [Internet]. 2016 Oct 12;355:i4919-i4919. Available from: https://pubmed.ncbi.nlm.nih.gov/27733354

21. Kumaira Fonseca M, Trindade EN, Costa Filho OP, Nácul MP, Seabra AP. Impact of COVID -19 Outbreak on the Emergency Presentation of Acute Appendicitis. Am Surg [Internet]. 2020/11/06. 2020 Nov;86(11):1508-12. Available from: https://pubmed.ncbi.nlm.nih.gov/33156694

22. Tartaglia N, Pavone G, Lizzi V, Vovola F, Tricarico F, Pacilli M, et al. How emergency surgery has changed during the COVID -19 pandemic: A cohort study. Ann Med Surg [Internet]. 2020 Dec 5;60:686-9. Available from: https://pubmed.ncbi.nlm.nih.gov/33312562

23. Würnschimmel C, Maurer T, Knipper S, von Breunig F, Zoellner C, Thederan I, et al. Martini-Klinik experience of prostate cancer surgery during the early phase of the COVID -19 pandemic. BJU Int [Internet]. 2020 Aug 1;126(2):252-5. Available from: https://doi.org/10.1111/bju.15115

24. Sartori A, Podda M, Botteri E, Passera R, Agresta F, Arezzo A, et al. Appendectomy during the COVID -19 pandemic in Italy: a multicenter ambispective cohort study by the Italian Society of Endoscopic Surgery and new technologies (the CRAC study). Updates Surg [Internet]. 2021/07/04. 2021 Dec;73(6):2205-13. Available from: https://pubmed.ncbi.nlm.nih.gov/34219197

25. Jain S, Gupta S, Singh TP, Chhabra K, Jain R, Sohi AS, et al. Short Term Outcomes of Head and Neck Oncology Surgery During COVID -19 Pandemic: Experience from a Tertiary Cancer Care Centre in North India. Indian J Otolaryngol Head Neck Surg [Internet]. 2021 Jan 8;1-5. Available from: https://pubmed.ncbi.nlm.nih.gov/33437685 
26. Borgstein ABJ, Brunner S, Hayami M, Moons J, Fuchs H, Eshuis WJ, et al. Safety of Esophageal Cancer Surgery During the First Wave of the COVID -19 Pandemic in Europe: A Multicenter Study. Ann Surg Oncol [Internet]. 2021/04/08. 2021 Sep;28(9):4805-13. Available from: https://pubmed.ncbi.nlm.nih.gov/33830357

27. Hugo TF, Jérôme G, Mare Luca D, Pierre F, Riadh K, Andrew M, et al. Appendicitis and cholecystitis during the COVID -19 outbreak: A multicentre experience. Swiss Med Wkly. 2021;151(33-34).

28. Malik A, Zohdy M, Ahmad A, Seretis C. Single-centre experience of emergency hernia surgery during COVID -19 pandemic: A comparative study of the operative activity and outcomes before and after the outbreak. Med Glas. 2021 Aug;18(2):463-7.

29. Rashid MU, Raza SS, Thomas P, Vakis S. Comparison of Colorectal Cancer Surgery Services During COVID -19 First Wave With Pre-COVID Time. Cureus [Internet]. 2021 Aug 30;13(8):e17585-e17585. Available from:

https://pubmed.ncbi.nlm.nih.gov/34522556

30. Panda S, Vig S, Singh CA, Konkimalla A, Thakar A, Sakthivel P, et al. Head and Neck Surgery During COVID -19 Pandemic: Experience from a Tertiary Care in India. Indian J Surg Oncol [Internet]. 2021 Sep 12;12(Suppl 2):279-89. Available from:

https://pubmed.ncbi.nlm.nih.gov/34539130

31. María FM, Lorena MR, María Luz FV, Cristina RV, Dolores PD, Fernando TF. Overall management of emergency general surgery patients during the surge of the COVID -19 pandemic: an analysis of procedures and outcomes from a teaching hospital at the worst hit area in Spain. Eur J Trauma Emerg Surg. 2021 Jun;47(3):693-702.

32. Vusirikala A, Saleh M, Laurent E, del Castillo T, Kuzhupilly RRR, Fahmy A, et al. Restarting Elective Orthopaedic Surgery During the COVID -19 Pandemic: Lessons Learned. Cureus [Internet]. 2021 Jul 12;13(7):e16343-e16343. Available from: https://pubmed.ncbi.nlm.nih.gov/34395125

33. Iqbal MR, Dhahri AA, Darwish NMM, Vijay V. Single centre concept of 'cold site' elective surgery during the peak of COVID -19 pandemic $\square$ : A cohort study. Ann Med Surg [Internet]. 2020;59:245-50. Available from: https://www.sciencedirect.com/science/article/pii/S2049080120303526

34. Rajasekaran RB, Kotecha S, Whitwell D, Cosker TDA, Critchley P, Fries CA, et al. Patient safety associated with the surgical treatment of bone and soft tissue tumours during the COVID -19 pandemic - results from an observational study at the Oxford Sarcoma Service. Int Orthop [Internet]. 2020/07/29. 2020 Sep;44(9):1853-8. Available from: https://pubmed.ncbi.nlm.nih.gov/32728926

35. Wahed S, Chmelo J, Navidi M, Hayes N, Phillips AW, Immanuel A. Delivering esophago-gastric cancer care during the COVID -19 pandemic in the United Kingdom: A surgical perspective. Dis Esophagus [Internet]. 2020 Sep 4;33(9):doaa091. Available from: https://pubmed.ncbi.nlm.nih.gov/32816020

36. Minervini A, Di Maida F, Mari A, Porreca A, Rocco B, Celia A, et al. Perioperative outcomes of patients undergoing urological elective surgery during the COVID -19 
pandemic: A national overview across 28 italian institutions. Cent Eur J Urol [Internet]. 2021/04/22. 2021;74(2):259-68. Available from:

https://pubmed.ncbi.nlm.nih.gov/34336248

37. Romics L, Doughty J, Stallard S, Mansell J, Blackhall V, Lannigan A, et al. A prospective cohort study of the safety of breast cancer surgery during COVID -19 pandemic in the West of Scotland. Breast [Internet]. 2020/11/25. 2021 Feb;55:1-6. Available from: https://pubmed.ncbi.nlm.nih.gov/33285400

38. Singhal R, Ludwig C, Rudge G, Gkoutos G V., Tahrani A, Mahawar K, et al. 30-Day Morbidity and Mortality of Bariatric Surgery During the COVID -19 Pandemic: a Multinational Cohort Study of 7704 Patients from 42 Countries. Obes Surg [Internet]. 2021/07/30. 2021 Oct;31(10):4272-88. Available from:

https://pubmed.ncbi.nlm.nih.gov/34328624

39. Clifford RE, Rajput K, Naing CY, MacDonald K, Pantak T, Kaul A. Reducing waiting lists for laparoscopic cholecystectomy: An intensive approach to aid COVID -19 recovery. Eur Surg - Acta Chir Austriaca [Internet]. 2021 Jun 14;1-4. Available from: https://pubmed.ncbi.nlm.nih.gov/34149832

40. Dinçer MB, Güler MM, Gök AFK, İlhan M, Orhan-Sungur M, Özkan-Seyhan T, et al. Evaluation of Postoperative Complication with Medically Necessary, Time-Sensitive Scoring System During Acute COVID -19 Pandemic: A Prospective Observational Study. J Am Coll Surg [Internet]. 2021/06/07. 2021 Sep;233(3):435-444.e1. Available from: https://pubmed.ncbi.nlm.nih.gov/34111533

41. Jeannon JP, Simo R, Oakley R, Townley W, Orfaniotis G, Fry A, et al. Head and neck cancer surgery during the coronavirus pandemic: A single-institution experience. $\mathrm{J}$ Laryngol Otol [Internet]. 2021/02/01. 2021 Feb;135(2):168-72. Available from: https://pubmed.ncbi.nlm.nih.gov/33517925

42. María F-M, Lorena M-R, María Luz F-V, Cristina R-V, Dolores P-D, Fernando T-F, et al. Is elective cancer surgery feasible during the lock-down period of the COVID -19 pandemic? Analysis of a single institutional experience of 404 consecutive patients. J Surg Oncol [Internet]. 2021/02/23. 2021 Jun;123(7):1495-503. Available from: https://pubmed.ncbi.nlm.nih.gov/33621377

43. Kasivisvanathan V, Lindsay J, Rakshani-Moghadam S, Elhamshary A, Kapriniotis K, Kazantzis G, et al. A cohort study of 30 day mortality after NON-EMERGENCY surgery in a COVID -19 cold site. Int J Surg [Internet]. 2020/10/24. 2020 Dec;84:57-65. Available from: https://pubmed.ncbi.nlm.nih.gov/33122153

44. Romanzi A, Moroni R, Rongoni E, Scolaro R, Regina D La, Mongelli F, et al. The management of "fragile" and suspected COVID -19 surgical patients during pandemic: An Italian single-center experience. Minerva Chir. 2020 Oct;75(5):320-7.

45. Romanzi A, Boleso N, Di Palma G, La Regina D, Mongelli F, Milanesi M, et al. Awake Major Abdominal Surgeries in the COVID -19 Era. Pain Res Manag [Internet]. 2021 Feb 22;2021:8763429. Available from: https://pubmed.ncbi.nlm.nih.gov/33688385

46. Zagra L, D’ Apolito R, Guindani N, Zatti G, Rivera F, Ravasi F, et al. Do standards of care 
and early outcomes of periprosthetic fractures change during the COVID -19 pandemic? A multicentre study. J Orthop Traumatol [Internet]. 2021 Jun 14;22(1):22. Available from: https://pubmed.ncbi.nlm.nih.gov/34128114

47. Monroy-Iglesias MJ, Tagliabue M, Dickinson H, Roberts G, De Berardinis R, Russell B, et al. Continuity of cancer care: The surgical experience of two large cancer hubs in london and milan. Cancers (Basel) [Internet]. 2021 Mar 30;13(7):1597. Available from: https://pubmed.ncbi.nlm.nih.gov/33808375

48. Brar S, Ofo E, Hyde N, Kim D, Odutoye T, Allin D, et al. Outcomes of elective head and neck confirmed or suspected cancer surgery during the COVID -19 pandemic. Eur Arch Oto-Rhino-Laryngology [Internet]. 2020/07/15. 2021 Apr;278(4):1277-82. Available from: https://pubmed.ncbi.nlm.nih.gov/32671539

49. Gammeri E, Cillo GM, Sunthareswaran R, Magro T. Is a "COVID -19-free" hospital the answer to resuming elective surgery during the current pandemic? Results from the first available prospective study. Surg (United States) [Internet]. 2020/07/15. 2020 Oct;168(4):572-7. Available from: https://pubmed.ncbi.nlm.nih.gov/32739140

50. Castellvi J, Jerico C, DeMiguel A, Camacho D, Mullerat JM, Catala J, et al. Impact on clinical practice of the preoperative screening of COVID -19 infection in surgical oncological patients. Prospective cohort study. Int J Surg Open [Internet]. 2020;26:30-5. Available from: https://www.sciencedirect.com/science/article/pii/S2405857220300589

51. Rottoli M, Pellino G, Tanzanu M, Baldi C, Frontali A, Carvello M, et al. Inflammatory Bowel Disease patients requiring surgery can be treated in referral centres regardless of the COVID -19 status of the hospital: results of a multicentric European study during the first COVID -19 outbreak (COVIBD-Surg). Updates Surg [Internet]. 2021/06/26. 2021 Oct;73(5):1811-8. Available from: https://pubmed.ncbi.nlm.nih.gov/34176073

52. Das R, Nahak SR, Parija J, Das PK, Sarangi L, Devi P, et al. Optimising Cancer Surgery During COVID -19: Experience of Tertiary Cancer Centre in Eastern India. Indian J Gynecol Oncol [Internet]. 2021/03/26. 2021;19(2):29. Available from: https://pubmed.ncbi.nlm.nih.gov/33786366

53. Evans S, Taylor C, Antoniou A, Agarwal T, Burns E, Jenkins JT, et al. Implementation of a clinical pathway for the surgical treatment of colorectal cancer during the COVID -19 pandemic. Color Dis [Internet]. 2020 Sep 1;22(9):1002-5. Available from: https://doi.org/10.1111/codi.15247

54. De Santiago J, Yelo C, F Chereguini M, Conde A, Galipienzo J, Salvatierra D, et al. COVID -19: Gynecologic cancer surgery at a single center in Madrid. Int J Gynecol Cancer [Internet]. 2020/07/07. 2020 Aug;30(8):1108-12. Available from: https://pubmed.ncbi.nlm.nih.gov/32641394

55. Lei S, Jiang F, Su W, Chen C, Chen J, Mei W, et al. Clinical characteristics and outcomes of patients undergoing surgeries during the incubation period of COVID -19 infection. EClinicalMedicine. 2020;21:100331.

56. Collaborative COVID . COVID Surg Collaborative. Mortality and pulmonary complications in patients undergoing surgery with perioperative SARS-CoV-2 infection: 
an international cohort study (vol 396, pg 27, 2020). Lancet. 2020;238.

57. Abbott TEF, Fowler AJ, Dobbs TD, Gibson J, Shahid T, Dias P, et al. Mortality after surgery with SARS-CoV-2 infection in England: a population-wide epidemiological study. Br J Anaesth. 2021 Aug;127(2):205-14.

58. Knisely A, Zhou ZN, Wu J, Huang Y, Holcomb K, Melamed A, et al. Perioperative Morbidity and Mortality of Patients With COVID -19 Who Undergo Urgent and Emergent Surgical Procedures. Ann Surg. 2021 Jan;273(1):34-40.

59. Kaufman EJ, Ong AW, Cipolle MD, Whitehorn G, Ratnasekera A, Stawicki SP, et al. The impact of COVID -19 infection on outcomes after injury in a state trauma system. J Trauma Acute Care Surg. 2021 Sep;91(3):559-65.

60. Nachon-Acosta A, Martinez-Mier G, Flores-Gamboa V, Avila-Mercado O, Garcia IM, Yoldi-Aguirre C, et al. Surgical Outcomes During COVID -19 Pandemic. Arch Med Res [Internet]. 2021/01/22. 2021 May;52(4):434-42. Available from: https://pubmed.ncbi.nlm.nih.gov/33618912

61. Mavrothalassitis O, Pirracchio R, Fong N, Lazzareschi D, Sharma A, Vaughn MT, et al. Outcome of surgical patients during the first wave of the COVID -19 pandemic in US hospitals. Br J Anaesth [Internet]. 2021/10/01. 2022 Jan;128(1):e35-7. Available from: https://pubmed.ncbi.nlm.nih.gov/34689990

62. Ciarleglio FA, Rigoni M, Mereu L, Tommaso C, Carrara A, Malossini G, et al. The negative effects of COVID -19 and national lockdown on emergency surgery morbidity due to delayed access. World J Emerg Surg [Internet]. 2021;16(1):37. Available from: https://doi.org/10.1186/s13017-021-00382-z

63. Bouthillier M-E, Lorange M, Legault S, Wade L, Dahine J, Latreille J, et al. Prioritizing surgery during the COVID -19 pandemic: the Quebec guidelines. Can J Surg [Internet]. 2021 Feb 18;64(1):E103-7. Available from: https://pubmed.ncbi.nlm.nih.gov/33599462

64. Moletta L, Pierobon ES, Capovilla G, Costantini M, Salvador R, Merigliano S, et al. International guidelines and recommendations for surgery during COVID -19 pandemic: A Systematic Review. Int J Surg. 2020 Jul;79:180-8.

65. Clement ND, Hall AJ, Makaram NS, Robinson PG, Patton RFL, Moran M, et al. IMPACT-Restart: the influence of COVID -19 on postoperative mortality and risk factors associated with SARS-CoV-2 infection after orthopaedic and trauma surgery. Bone Joint J. 2020 Dec;102-B(12):1774-81.

66. Glasbey JC, Nepogodiev D, Simoes JFF, Omar O, Li E, Venn ML, et al. Elective Cancer Surgery in COVID -19-Free Surgical Pathways During the SARS-CoV-2 Pandemic: An International, Multicenter, Comparative Cohort Study. J Clin Oncol Off J Am Soc Clin Oncol. 2021 Jan;39(1):66-78.

67. Pryor A. SAGES AND EAES RECOMMENDATIONS REGARDING SURGICAL RESPONSE TO COVID -19 CRISIS [Internet]. 2020. Available from: https://www.sages.org/recommendations-surgical-response-COVID -19/

68. Di Saverio S, Podda M, De Simone B, Ceresoli M, Augustin G, Gori A, et al. Diagnosis 
medRxiv preprint doi: https://doi.org/10.1101/2022.02.25.22271519; this version posted February 27, 2022. The copyright holder for this preprint

(which was not certified by peer review) is the author/funder, who has granted medRxiv a license to display the preprint in perpetuity.

It is made available under a CC-BY-NC-ND 4.0 International license .

and treatment of acute appendicitis: 2020 update of the WSES Jerusalem guidelines.

World J Emerg Surg [Internet]. 2020;15(1):27. Available from:

https://doi.org/10.1186/s13017-020-00306-3

69. Emile SH, Hamid HKS, Khan SM, Davis GN. Rate of Application and Outcome of Nonoperative Management of Acute Appendicitis in the Setting of COVID -19: Systematic Review and Meta-analysis. J Gastrointest Surg [Internet]. 2021/03/26. 2021

Jul;25(7):1905-15. Available from: https://pubmed.ncbi.nlm.nih.gov/33772399

70. Zemmar A, Lozano AM, Nelson BJ. The rise of robots in surgical environments during COVID -19. Nat Mach Intell [Internet]. 2020;2(10):566-72. Available from: https://doi.org/10.1038/s42256-020-00238-2

71. Morris L. mRNA vaccines offer hope for HIV. Nat Med [Internet]. 2021;27(12):2082-4. Available from: https://doi.org/10.1038/s41591-021-01602-4

72. Hanna TP, King WD, Thibodeau S, Jalink M, Paulin GA, Harvey-Jones E, et al. Mortality due to cancer treatment delay: systematic review and meta-analysis. bmj. 2020;371. 
medRxiv preprint doi: https://doi.org/10.1101/2022.02.25.22271519; this version posted February 27, 2022. The copyright holder for this preprint (which was not certified by peer review) is the author/funder, who has granted medRxiv a license to display the preprint in perpetuity.

It is made available under a CC-BY-NC-ND 4.0 International license.

Records identified through databases

$(\mathrm{n}=909)$

PubMed/Medline: 451

Scopus: 458

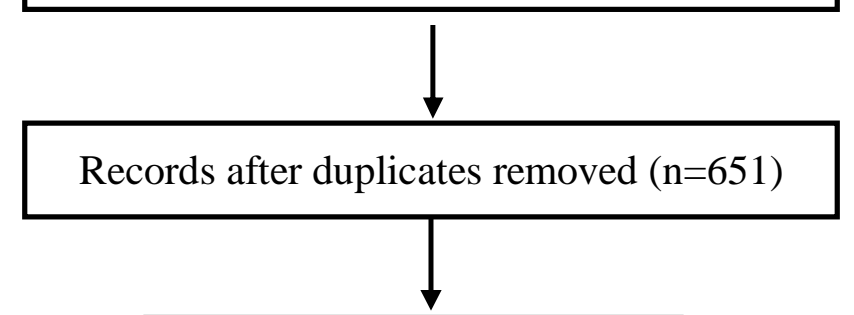

崽

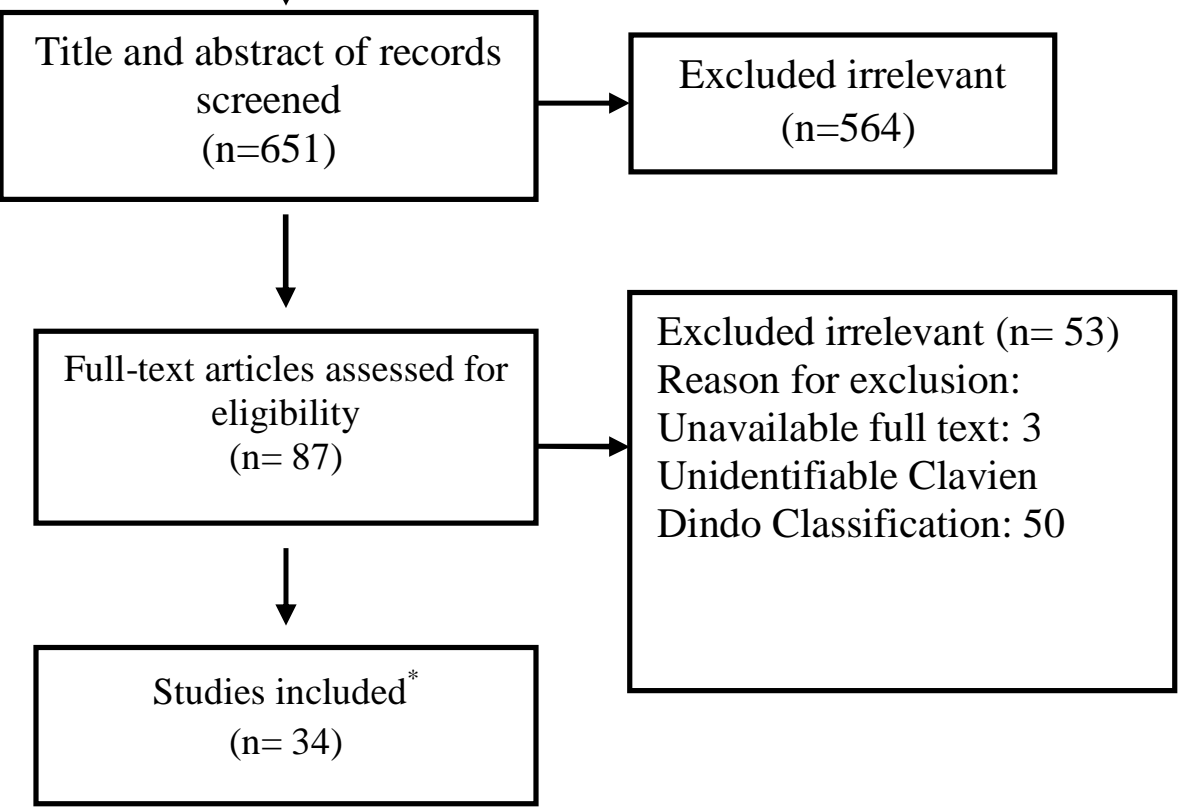

Figure 1. Flow chart of study selection for inclusion in the systematic review

*Total number of 34 articles reviewed qualitatively and included in systematic review, 11 of them were assessed quantitively for meta- analysis too. 
Table 1. Characteristics of the included studies. The first 11 studies are used for meta- analysis. med: Median; NM: Not mentioned.

\begin{tabular}{|c|c|c|c|c|c|c|c|}
\hline First Author & $\begin{array}{l}\text { Date of } \\
\text { publication }\end{array}$ & Country & $\begin{array}{l}\text { Type of } \\
\text { study }\end{array}$ & Population & $\begin{array}{l}\text { Pre COVID } \\
\text { Vs. COVID } \\
\text { Era }\end{array}$ & $\begin{array}{l}\text { Male: Female } \\
\text { ratio }\end{array}$ & $\begin{array}{l}\text { Mean age } \\
\text { (years) }\end{array}$ \\
\hline Fonseca et al. (21) & 2020, Nov & Brazil & Cohort & 118 & $82: 36$ & 47: 71 & 35.5 \\
\hline Tartaglia et al. (22) & 2020, Dec & USA & Cohort & 143 & $91: 52$ & $78: 65$ & 64.85 \\
\hline $\begin{array}{l}\text { Würnschimmel et al. } \\
\text { (23) }\end{array}$ & 2020, Aug & Germany & Cohort & 784 & 447: 337 & 784: 0 & 64 \\
\hline Sartori et al. (24) & 2021, July & Italy & Cohort & 1336 & $791: 546$ & 449: 388 & 37.84 \\
\hline Jain et al. (25) & 2021, Jan & India & Cohort & 127 & $59: 68$ & $84: 44$ & 52.4 \\
\hline Borgstein et al. (26) & 2021, Apr & Netherlands & Cohort & 307 & 168: 139 & 257: 50 & 66.45 \\
\hline Hugo et al.(27) & 2021, Aug & Switzerland & Cohort & 214 & 115: 99 & 111: 103 & 42.5 \\
\hline Malik et al. (28) & 2021, Jun & UK & Cohort & 71 & $32: 39$ & $43: 28$ & 66.8 \\
\hline Rashid et al. (29) & 2021, Aug & UK & Cohort & 32 & $10: 22$ & 16: 6 & 74.2 \\
\hline Panda et al. (30) ${ }^{1}$ & 2021, Sep & India & Cohort & 64 & $32: 32$ & 52: 12 & 47.34 \\
\hline $\begin{array}{l}\text { Fernández } \square \text { Martínez } \\
\text { et al. (31) }\end{array}$ & 2021, Jun & Spain & Cohort & 235 & 135: 100 & NM & NM \\
\hline Vusirikala et al. (32) & 2021, Jul & UK & Cohort & 104 & $0: 104$ & 59: 45 & 59 \\
\hline Iqbal et al. (33) & 2020, Oct & UK & Cohort & 153 & $0: 153$ & $58: 95$ & 57 \\
\hline Rajasekaran et al. (34) & 2020, Sep & UK & Cohort & 56 & $0: 56$ & $30: 26$ & 57 (med) \\
\hline Wahed et al. (35) & 2020, Aug & UK & Cohort & 19 & $0: 19$ & $15: 4$ & 70 (med) \\
\hline Minervini et al. (36) & 2021, Apr & Italy & Cohort & 1943 & $0: 1943$ & NM & 67 (med) \\
\hline Romics et al. (37) & 2020, Nov & UK & Cohort & 179 & $0: 179$ & $0: 179$ & 54 (med) \\
\hline Singhal et al. (38) & 2021, May & UK & Cohort & 7704 & $0: 7704$ & 1886: 519 & 40.35 \\
\hline Clifford et al. (39) & 2021, Jun & UK & Cohort & 21 & $0: 21$ & $3: 18$ & 53 (med) \\
\hline Dinçer et al. (40) & 2021, Sep & Turkey & Cohort & 223 & $0: 223$ & 112: 111 & 48.5 \\
\hline Jeannon et al. (41) & 2021, Jan & UK & Cohort & 69 & $0: 69$ & $\mathrm{NM}$ & 52 \\
\hline Kulle et al. (42) & 2021, Feb & Turkey & Cohort & 404 & $0: 404$ & NM & 61 (med) \\
\hline $\begin{array}{l}\text { Kasivisvanathan et al. } \\
\text { (43) }\end{array}$ & 2020, Oct & UK & Cohort & 500 & $0: 500$ & $327: 173$ & 62.5 (med) \\
\hline ROMANZI et al.(44) & 2020, Oct & Switzerland & Cohort & 18 & $0: 18$ & $8: 10$ & 73.2 \\
\hline Romanzi et al. (45) & 2021, Feb & Italy & Cohort & 13 & $0: 13$ & $5: 8$ & 80 \\
\hline Zagra et al. (46) & 2021, Jun & Italy & Cohort & 38 & $0: 38$ & $12: 26$ & 81 \\
\hline $\begin{array}{l}\text { Monroy-Iglesias et al. } \\
\text { (47) }\end{array}$ & 2021, Mar & UK & Cohort & 3037 & 1560: 1477 & 1707: 1330 & 62.49 \\
\hline Brar et al. (48) & 2021, Jul & UK & Cohort & 47 & $0: 47$ & $31: 16$ & NM \\
\hline Gammeri et al. (49) & 2020, Jul & UK & Cohort & 309 & $0: 309$ & 142: 167 & 61.9 \\
\hline Castellvi et al. (50) & 2020, Aug & Spain & Cohort & 171 & $0: 171$ & $97: 83^{2}$ & 65.7 \\
\hline Rottoli et al. (51) & 2021, Jun & Italy & Cohort & 91 & $0: 91$ & 59: 32 & 43 \\
\hline Das et al. (52) & 2021, Mar & India & Cohort & 457 & $0: 457$ & NM & 50 (med) \\
\hline Evans et al. (53) & 2021, Jul & UK & Cohort & 23 & $0: 23$ & $16: 7$ & 65 \\
\hline Santiago et al. (54) & $2020, \mathrm{Jul}$ & Spain & Cohort & 126 & $0: 126$ & NM & 67 (med) \\
\hline
\end{tabular}

1 The matched groups are considered.

2 Some of the patients managed non- operatively. The study population refers to the number of surgery but the gender specification has considered all the patients. 
Table 2. The Meta- analysis of the incidence of each grade of surgical complications and its publication bias due to Clavien- Dindo classification.

\begin{tabular}{|c|c|c|c|c|c|c|c|}
\hline Grade & $\begin{array}{c}\text { Estimate } \\
\text { point }\end{array}$ & $\begin{array}{c}\text { Lower } \\
\text { limit }\end{array}$ & $\begin{array}{c}\text { Upper } \\
\text { limit }\end{array}$ & P value & I squared & Begg & Egger \\
\hline $\mathbf{1}$ & 0.988 & 0.600 & 1.626 & 0.961 & 48.289 & 0.251 & 0.003 \\
\hline $\mathbf{2}$ & 0.649 & 0.418 & 1.009 & 0.055 & 58.587 & 0.371 & 0.555 \\
\hline $\mathbf{3}$ & 0.868 & 0.479 & 1.573 & 0.641 & 60.482 & 1.000 & 0.960 \\
\hline $\mathbf{4}$ & 0.848 & 0.457 & 1.572 & 0.600 & 28.217 & 1.000 & 0.733 \\
\hline $\mathbf{5}$ & 0.510 & 0.272 & 0.955 & 0.035 & 0 & 0.734 & 0.598 \\
\hline
\end{tabular}

Table 3. The performed surgeries by urgency and related organ- system

\begin{tabular}{|c|c|c|c|}
\hline $\begin{array}{c}\text { Categorization } \\
\text { basis }\end{array}$ & Categories & Absolute frequency (n) & Relative frequency (\%) \\
\hline \multirow{4}{*}{ Urgency } & Immediate & 327 & 1.71 \\
\cline { 2 - 4 } & Urgent & 2150 & 11.22 \\
\cline { 2 - 4 } & Expedited & 145 & 0.76 \\
\cline { 2 - 4 } & Elective & 16547 & 86.32 \\
\cline { 2 - 4 } & Neurosurgery & 52 & 0.28 \\
\cline { 2 - 4 } & Cardiothoracic & 1321 & 7.19 \\
\cline { 2 - 4 } & Non-vascular & 9594 & 52.19 \\
\cline { 2 - 4 } & Abdominal & 5180 & 28.18 \\
\cline { 2 - 4 } & Gynaecology / Urology & 649 & 3.53 \\
\cline { 2 - 4 } & Breast & 260 & 1.41 \\
\cline { 2 - 4 } & Orthopaedics & 819 & 4.46 \\
\cline { 2 - 4 } & Head and neck & 185 & 1.01 \\
\cline { 2 - 4 } & Plastic & 4 & 0.02 \\
\cline { 2 - 4 } & Ophthalmic & 319 & 1.74 \\
\hline
\end{tabular}

*Others includes soft tissue and bone sarcoma surgery, endocrine surgery, and other unspecified surgeries. The discrepancy between the total number of surgeries between two categorization system is due to unnoted surgical fields in some of the reviewed studies. 
Table 4. The incidence of post operative surgical complications due to Clavien- Dindo classification during the COVID era.

\begin{tabular}{|c|c|c|c|c|c|c|}
\hline \multirow[t]{2}{*}{ First author } & \multirow{2}{*}{$\begin{array}{c}\text { COVID } \\
\text { Era } \\
\text { sample } \\
\text { size } \\
\end{array}$} & \multicolumn{5}{|c|}{ Clavien- Dindo Classification grades } \\
\hline & & 1 & 2 & 3 & 4 & 5 \\
\hline Fonseca et al. (21) & 36 & 5 & 3 & 3 & 0 & 0 \\
\hline Tartaglia et al. (22) & 52 & 4 & 7 & 1 & 5 & 12 \\
\hline $\begin{array}{c}\text { Würnschimmel et al. } \\
\text { (23) }\end{array}$ & 337 & 21 & 26 & 13 & 2 & 0 \\
\hline Sartori et al. (24) & 546 & 402 & 108 & 29 & 3 & 1 \\
\hline Jain et al. (25) & 68 & 1 & 0 & 5 & 1 & 0 \\
\hline Borgstein et al. (26) & 139 & 5 & 33 & 25 & 25 & 5 \\
\hline Hugo et al.(27) & 99 & 4 & 5 & 3 & 0 & 0 \\
\hline Malik et al. (28) & 39 & 0 & 7 & 4 & 0 & 0 \\
\hline Rashid et al. (29) & 22 & 18 & 4 & 0 & 0 & 0 \\
\hline Panda et al. $(30)^{3}$ & 32 & 2 & 10 & 2 & 1 & 0 \\
\hline $\begin{array}{c}\text { Fernández } \square \text { Martínez et } \\
\text { al. (31) }\end{array}$ & 100 & 0 & 9 & 10 & 9 & 7 \\
\hline Vusirikala et al. (32) & 104 & 5 & 5 & 1 & 0 & 0 \\
\hline Iqbal et al. (33) & 153 & 1 & 6 & 0 & 0 & 0 \\
\hline Rajasekaran et al. (34) & 56 & 2 & 0 & 11 & 0 & 0 \\
\hline Wahed et al. (35) & 19 & 0 & 5 & 1 & 1 & 0 \\
\hline Minervini et al. (36) & 1943 & 26 & 32 & 18 & 0 & 1 \\
\hline Romics et al. (37) & 179 & 7 & 2 & 4 & 0 & 0 \\
\hline Singhal et al. (38) & 7704 & 193 & 158 & 160 & 46 & 10 \\
\hline Clifford et al. (39) & 21 & 0 & 2 & 0 & 0 & 0 \\
\hline Dinçer et al. (40) & 223 & 23 & 35 & 36 & 0 & 8 \\
\hline Jeannon et al. (41) & 69 & 4 & 7 & 0 & 0 & 0 \\
\hline Kulle et al. (42) & 404 & 11 & 29 & 32 & 2 & 5 \\
\hline $\begin{array}{c}\text { Kasivisvanathan et al. } \\
\text { (43) }\end{array}$ & 500 & NM & NM & 16 & 14 & 3 \\
\hline ROMANZI et al.(44) & 18 & 0 & 1 & 1 & 0 & 0 \\
\hline Romanzi et al. (45) & 13 & 0 & 1 & 0 & 0 & 0 \\
\hline Zagra et al. (46) & 38 & 3 & 6 & 16 & 6 & 5 \\
\hline $\begin{array}{c}\text { Monroy-Iglesias et al. } \\
(47)\end{array}$ & 1477 & 92 & 81 & 37 & 26 & 3 \\
\hline Brar et al. (48) & 47 & 2 & 5 & 1 & 0 & 0 \\
\hline Gammeri et al. (49) & 309 & 13 & 12 & 2 & 0 & 0 \\
\hline Castellvi et al. (50) & 171 & 26 & 0 & 4 & 0 & 0 \\
\hline Rottoli et al. (51) & 91 & 1 & 13 & 5 & 1 & 0 \\
\hline Das et al. (52) & 457 & 375 & 78 & 2 & 0 & 2 \\
\hline
\end{tabular}

3 The matched groups are considered. 
medRxiv preprint doi: https://doi.org/10.1101/2022.02.25.22271519; this version posted February 27, 2022. The copyright holder for this preprint (which was not certified by peer review) is the author/funder, who has granted medRxiv a license to display the preprint in perpetuity.

It is made available under a CC-BY-NC-ND 4.0 International license .

\begin{tabular}{|c|c|c|c|c|c|c|}
\hline Evans et al. (53) & 23 & 6 & 4 & 0 & 0 & 0 \\
\hline Santiago et al. (54) & 126 & 9 & 4 & 1 & 1 & 0 \\
\hline
\end{tabular}

Table 5. The incidence of surgical complications due to Clavien- Dindo classification before and during the COVID -19 era.

\begin{tabular}{|c|c|c|c|c|c|c|c|c|c|c|c|c|c|}
\hline \multirow{3}{*}{ First author } & \multirow{3}{*}{$\begin{array}{c}\text { Total } \\
\text { population }\end{array}$} & \multicolumn{6}{|c|}{ Pre COVID--19 Era } & \multicolumn{6}{|c|}{ COVID Era } \\
\hline & & \multirow{2}{*}{ sample size } & \multicolumn{5}{|c|}{ Article CDC } & \multirow{2}{*}{ sample size } & \multicolumn{5}{|c|}{ Article CDC } \\
\hline & & & 1 & 2 & 3 & 4 & 5 & & 1 & 2 & 3 & 4 & 5 \\
\hline Tartaglia et al. (22) & 143 & 91 & 3 & 5 & 5 & 1 & 12 & 52 & 4 & 7 & 1 & 5 & 12 \\
\hline $\begin{array}{l}\text { Würnschimmel et } \\
\text { al. (23) }\end{array}$ & 784 & 447 & 35 & 44 & 22 & 5 & 0 & 337 & 21 & 26 & 13 & 2 & 0 \\
\hline Jain et al (25) & 127 & 59 & 1 & 0 & 2 & 1 & 0 & 68 & 1 & 0 & 5 & 1 & 0 \\
\hline Borgstein et al. (26) & 307 & 168 & 8 & 35 & 39 & 24 & 2 & 139 & 5 & 33 & 25 & 25 & 5 \\
\hline Hugo et al. (27) & 214 & 115 & 4 & 5 & 0 & 0 & 0 & 99 & 4 & 5 & 3 & 0 & 0 \\
\hline Malik et al. (28) & 71 & 32 & 0 & 10 & 2 & 0 & 0 & 39 & 0 & 7 & 4 & 0 & 0 \\
\hline $\begin{array}{l}\text { Fernández-Martínez } \\
\text { et al. (31) }\end{array}$ & 235 & 135 & 0 & 3 & 6 & 6 & 5 & 100 & 0 & 9 & 10 & 9 & 7 \\
\hline
\end{tabular}

Figures 2- 6. The Forest Plot of each grade.

Clavien-Dindo Grade 1

\begin{tabular}{|c|c|c|c|c|c|c|c|c|c|}
\hline Study name & $\begin{array}{l}\text { Prepandemic } \\
\text { events }\end{array}$ & $\begin{array}{l}\text { Pandemic } \\
\text { events }\end{array}$ & $\begin{array}{l}\text { Odds } \\
\text { ratio }\end{array}$ & $\begin{array}{l}\text { Lower } \\
\text { limit }\end{array}$ & $\begin{array}{l}\text { Upper } \\
\text { limt }\end{array}$ & Z-Value & p-Value & Odds ratio and $95 \% \mathrm{Cl}$ & $\begin{array}{c}\text { Relative } \\
\text { welght }\end{array}$ \\
\hline $\begin{array}{l}\text { Fonseca et al. } \\
\text { Tartaglia et al. } \\
\text { WOrnschimmel et al. } \\
\text { Sartorl et al. } \\
\text { Jain et al } \\
\text { Borgstein et al. } \\
\text { Hugn et al } \\
\text { Rachid ot al. } \\
\text { Panda ot al. }\end{array}$ & $\begin{array}{l}3 / 82 \\
3 / 93 \\
35 / 447 \\
664 / 791 \\
1 / 59 \\
8 / 168 \\
41115 \\
7 / 110 \\
32 / 64 \\
725 / 1962\end{array}$ & $\begin{array}{l}b / 36 \\
5 / 36 \\
21 / 337 \\
402 / 546 \\
1 / 68 \\
5 / 139 \\
4 / 99 \\
18 / 22 \\
2 / 32 \\
482 / 1470\end{array}$ & $\begin{array}{l}0.235 \\
0.409 \\
1.278 \\
1.873 \\
1.155 \\
1.340 \\
0.856 \\
0.619 \\
0.188 \\
0.988\end{array}$ & $\begin{array}{l}0.053 \\
0.088 \\
0.730 \\
1.431 \\
0.071 \\
0.428 \\
0.208 \\
0.092 \\
0.009 \\
0.600\end{array}$ & $\begin{array}{l}1.046 \\
1.904 \\
2.239 \\
2.450 \\
18.883 \\
4.193 \\
3.515 \\
2.933 \\
4.069 \\
1.626\end{array}$ & $\begin{array}{l}-1.902 \\
-1.139 \\
0.859 \\
4.575 \\
0.101 \\
0.503 \\
-0.216 \\
-0.743 \\
-1.068 \\
-0.049\end{array}$ & $\begin{array}{l}0.031 \\
0.255 \\
0.391 \\
0.000 \\
0.919 \\
0.615 \\
0.829 \\
0.468 \\
0.288 \\
0.981\end{array}$ & & $\begin{array}{r}8.25 \\
7.87 \\
22.47 \\
28.77 \\
2.89 \\
11.87 \\
8.91 \\
6.65 \\
2.42\end{array}$ \\
\hline & & & & & & & & $\begin{array}{llr}0.1 & 1 & 10 \\
\text { OVID-18 Ema } & \text { coviD }\end{array}$ & \\
\hline
\end{tabular}


medRxiv preprint doi: https://doi.org/10.1101/2022.02.25.22271519; this version posted February 27, 2022. The copyright holder for this preprint (which was not certified by peer review) is the author/funder, who has granted medRxiv a license to display the preprint in perpetuity.

It is made available under a CC-BY-NC-ND 4.0 International license .

Clavlen-DIndo Grade 2

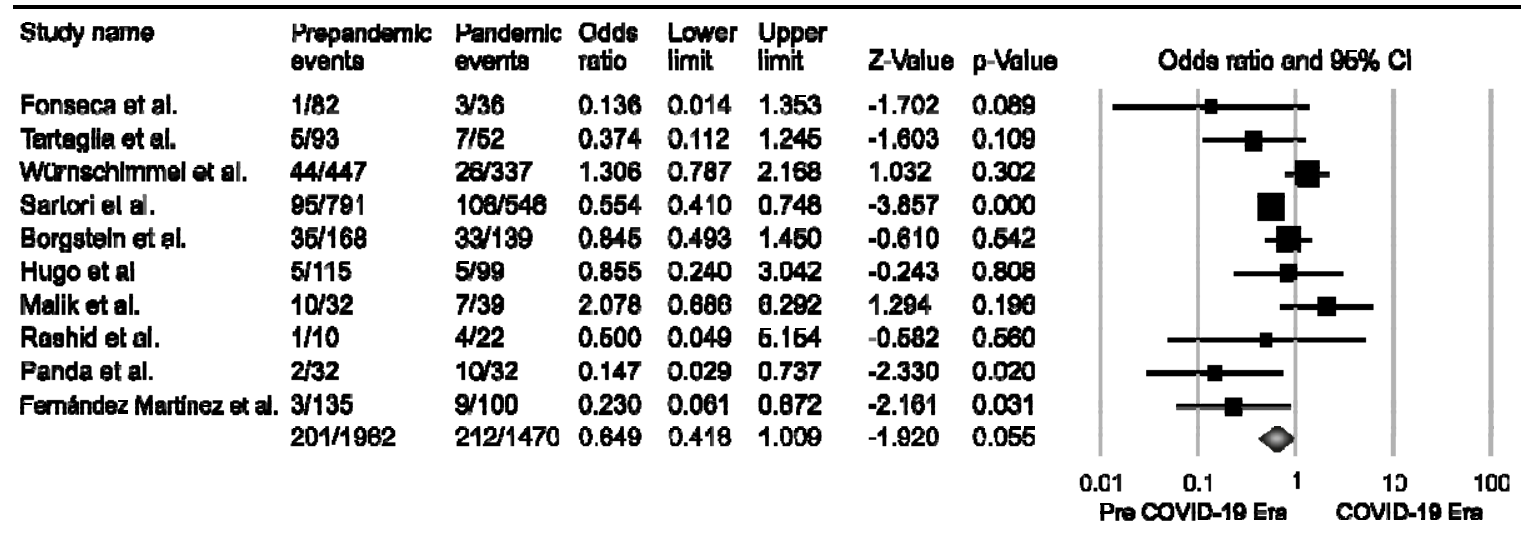

Clavien-Dindo Grade 3

\begin{tabular}{|c|c|c|c|c|c|c|c|c|}
\hline 9tuxty name & $\begin{array}{l}\text { Prepandemls } \\
\text { events }\end{array}$ & $\begin{array}{l}\text { Pandemle: } \\
\text { events }\end{array}$ & $\begin{array}{l}\text { Odds } \\
\text { ratio }\end{array}$ & $\begin{array}{l}\text { Lowar } \\
\text { Ilmit }\end{array}$ & $\begin{array}{l}\text { Upper } \\
\text { Ilmit }\end{array}$ & Z-Value & p-Value & Odds ratlo and $95 \% \mathrm{Cl}$ \\
\hline $\begin{array}{l}\text { Fonseca ot al. } \\
\text { Tartaglla ot al. } \\
\text { Wirnschlmmel et al. } \\
\text { Sertorl ot al. } \\
\text { Jain et al } \\
\text { Borgstein et al. } \\
\text { Hugo et al } \\
\text { Mallk et al. } \\
\text { Rashld et al. } \\
\text { Panda ot al. } \\
\text { Femandez Martinez et al. }\end{array}$ & $\begin{array}{l}1 / 82 \\
5 / 91 \\
22 / 447 \\
19 / 791 \\
2 / 59 \\
39 / 168 \\
0 / 115 \\
2 / 32 \\
2 / 10 \\
9 / 32 \\
6 / 135 \\
107 / 1962\end{array}$ & $\begin{array}{l}3 / 36 \\
1 / 52 \\
13 / 337 \\
22 / 546 \\
5 / 68 \\
25 / 139 \\
3 / 99 \\
4 / 39 \\
0 / 22 \\
2 / 32 \\
10 / 100 \\
95 / 1470\end{array}$ & $\begin{array}{l}0.136 \\
2.965 \\
1.290 \\
0.439 \\
0.442 \\
1.379 \\
0.119 \\
0.583 \\
13.235 \\
5.870 \\
0.419 \\
0.868\end{array}$ & $\begin{array}{l}0.014 \\
0.337 \\
0.640 \\
0.243 \\
0.083 \\
0.786 \\
0.006 \\
0.100 \\
0.574 \\
1.155 \\
0.147 \\
0.479\end{array}$ & $\begin{array}{l}1.353 \\
26.094 \\
2.800 \\
0.791 \\
2.369 \\
2.418 \\
2.389 \\
3.411 \\
304.939 \\
29.822 \\
1.193 \\
1.673\end{array}$ & $\begin{array}{l}-1.702 \\
0.980 \\
0.713 \\
-2.741 \\
-0.953 \\
1.120 \\
1.400 \\
-0.598 \\
1.614 \\
2.134 \\
-1.630 \\
-0.467\end{array}$ & $\begin{array}{l}0.089 \\
0.327 \\
0.476 \\
0.006 \\
0.341 \\
0.269 \\
0.161 \\
0.550 \\
0.107 \\
0.033 \\
0.103 \\
0.641\end{array}$ & \\
\hline
\end{tabular}

Clavien-Dindo Grade 4

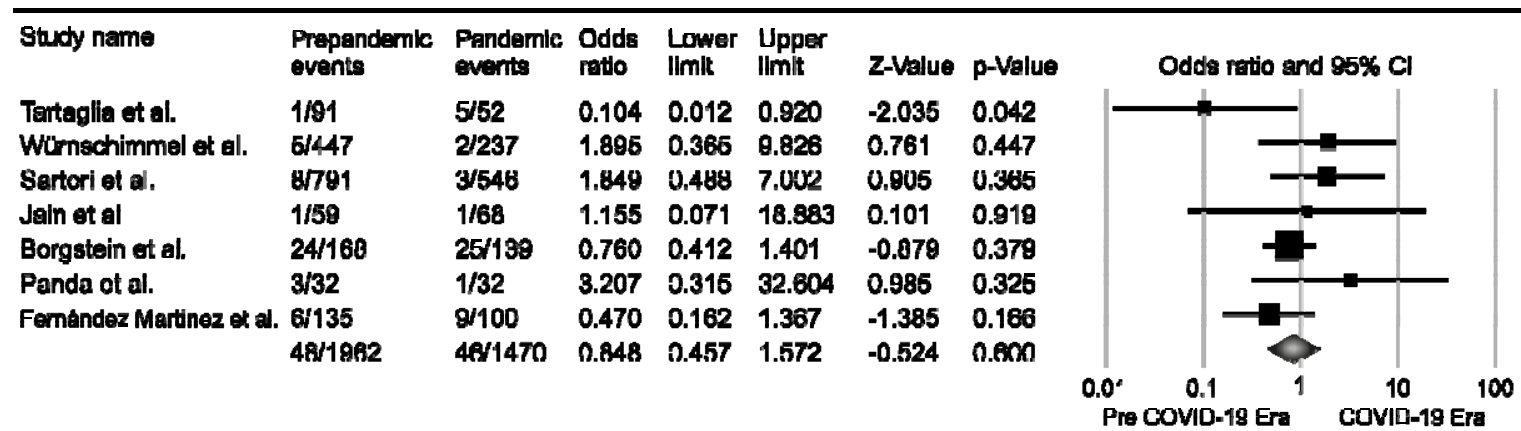

Clavien-Dindo Grade 5

\begin{tabular}{|c|c|c|c|c|c|c|c|c|}
\hline \multirow[t]{4}{*}{ Study name } & \multirow{3}{*}{$\begin{array}{l}\text { Prepandemlc } \\
\text { avents } \\
12 / 91 \\
2791\end{array}$} & \multirow{3}{*}{$\begin{array}{l}\text { Pandemlc } \\
\text { fvents } \\
12 / 52 \\
1 / 546\end{array}$} & \multirow{2}{*}{$\begin{array}{l}\text { Odds } \\
\text { ratio } \\
0.506\end{array}$} & \multirow{2}{*}{$\begin{array}{l}\text { Lower } \\
\text { limit } \\
0.209\end{array}$} & \multirow{3}{*}{$\begin{array}{l}\text { Upper } \\
\text { limit } \\
1.228 \\
15.273\end{array}$} & \multirow{2}{*}{$\begin{array}{l}\text { Z-Value } \\
-1.506\end{array}$} & \multirow{2}{*}{$\begin{array}{l}\text { p-Value } \\
0.132\end{array}$} & Odds ratio and $95 \% \mathrm{Cl}$ \\
\hline & & & & & & & & \\
\hline & & & 1.381 & 0.125 & & 0.264 & 0.792 & \\
\hline & $2 / 168$ & $5 / 139$ & 0.323 & 0.062 & 1.691 & -1.338 & 0.181 & \\
\hline Femńndez Martinez et el. & $6 / 135$ & $7 / 100$ & 0.611 & 0.167 & 1.660 & -1.117 & 0.264 & \\
\hline & $21 / 1962$ & $26 / 1470$ & 0.610 & 0.272 & 0.856 & -2.103 & 0.036 & \\
\hline
\end{tabular}


Figure 7. Adopted strategies and interventions during the pandemic to continue delivering surgery care

\begin{tabular}{|c|c|c|c|}
\hline Level of Intervention & Intervention & Description & Studies used this intervention \\
\hline $\begin{array}{l}\text { National and } \\
\text { provincial level }\end{array}$ & $\begin{array}{l}\text { COVID - } 19 \text { free } \\
\text { hospital }\end{array}$ & $\begin{array}{l}\text { Conducting a distinct hospital } \\
\text { for delivering surgery care to } \\
\text { avoid exposure of patients } \\
\text { with novel coronavirus }\end{array}$ & $(34,37,38,49,51)$ \\
\hline \multirow{5}{*}{ Hospital level } & $\begin{array}{l}\text { COVID -19 free } \\
\text { pathway }\end{array}$ & $\begin{array}{l}\text { Conducting a distinct pathway } \\
\text { for surgery care to avoid } \\
\text { exposure of patients with } \\
\text { novel coronavirus }\end{array}$ & $\begin{array}{l}(31,32,51- \\
53,33,36,39,41,43,45,46,48)\end{array}$ \\
\hline & Staff screening & $\begin{array}{l}\text { Routine screening of } \\
\text { asymptomatic staff }\end{array}$ & $(32,33,38)$ \\
\hline & $\begin{array}{l}\text { Patient Screening } \\
\text { via PCR }\end{array}$ & $\begin{array}{l}\text { Screening of patients before } \\
\text { surgery }\end{array}$ & $\begin{array}{l}(25,27,37,38,40-43,45,47- \\
49,28,50,51,53,54,30-36)\end{array}$ \\
\hline & $\begin{array}{l}\text { Patient Screening } \\
\text { via } \mathrm{CT}\end{array}$ & $\begin{array}{l}\text { Screening of patients before } \\
\text { surgery }\end{array}$ & $(35,40,43,50,53)$ \\
\hline & $\begin{array}{l}\text { Patient Screening } \\
\text { via CXR }\end{array}$ & $\begin{array}{l}\text { Screening of patients before } \\
\text { surgery }\end{array}$ & $(31,48,54)$ \\
\hline \multirow{4}{*}{ Department level } & $\begin{array}{l}\text { Patient Screening } \\
\text { via Symptom }\end{array}$ & $\begin{array}{l}\text { Screening of patients before } \\
\text { surgery (through a phone call } \\
\text { or interview) }\end{array}$ & $\begin{array}{l}(23,30,50,52,53,32- \\
34,37,42,43,47,49)\end{array}$ \\
\hline & $\begin{array}{l}\text { Different technique } \\
\text { and procedure }\end{array}$ & $\begin{array}{l}\text { When possible, using a } \\
\text { different type of surgery or } \\
\text { procedure to minimize risk of } \\
\text { COVID - } 19 \text { infection for staff } \\
\text { and other patients }\end{array}$ & $(23-25,35,45,52)$ \\
\hline & $\begin{array}{l}\text { Experienced } \\
\text { physician/operator }\end{array}$ & $\begin{array}{l}\text { Using experienced physician } \\
\text { to avoid exposure of junior } \\
\text { doctors and shorten the } \\
\text { duration of procedures }\end{array}$ & $(23,30,41,42,47,49,53)$ \\
\hline & Self-isolation & $\begin{array}{l}\text { Asking patient to be self- } \\
\text { isolate ( } 14 \text { days) prior to } \\
\text { planned time of surgery }\end{array}$ & $(25,32,53,33,35,37,38,41,43,47,48)$ \\
\hline
\end{tabular}

PCR: Polymerase chain reaction, CT: Computed tomography scan, CXR: Chest X-ray. 